DOI https://doi.org/10.18551/rjoas.2017-09.34

\title{
THE CORRELATION OF VEGETATIVE AND GENERATIVE CHARACTERS OF DUKU (LANSIUM DOMESTICUM CORR.) ACCESSION IN BANYUASIN REGENCY, SOUTH SUMATRA
}

\author{
Susilawati ${ }^{*}$, Ammar Muhammad, Priadi Dwi Putro, Robiartini Lucy, Irmawati \\ Department of Agronomy, Faculty of Agriculture, University of Sriwijaya \\ Juan Fitra \\ Department of Agroekoteknologi, Faculty of Agriculture, University of Sriwijaya \\ *E-mail: susilawati@fp.unsri.ac.id
}

\begin{abstract}
The development of duku plantation in other regencies is required to enrich duku germplasms in South Sumatra. Banyuasin Regency in South Sumatra was chosen as research location for this study since many duku plantations are located in this area.This research was aimed to observe the correlation of vegetative and generative characters of duku accession in Banyuasin Regency. The research was conducted for 10 months in 2017 located in three areas of Banyuasin Regency, which are Banyuasin $1\left(B_{1}\right)$, Banyuasin 2 $\left(\mathrm{BA}_{2}\right)$ and Banyuasin $3\left(\mathrm{BA}_{3}\right)$ with 5 plants per area resulting in total 15 plants. Purposive sampling method was used to determine the samples. Variability analysis and the calculation for correlation among vegetative and generative characters then were performed. Results showed that the characters of duku accessions indicated positive and negative correlation. Fruit sweetness level, however, did not show any correlation with either vegetative or generative characters.
\end{abstract}

\section{KEY WORDS}

Duku, plantations, fruits, characters, plants.

Indonesia with its tropical weather provides a favorable environment for growth and development of various fruit commodities, including for local Indonesian fruits. However, unfortunately, the local fruit is mostly not properly cultivated and well utilized. Fruit production in Indonesia increases year by year following the increasing demand of fruit consumption. Indonesian fruit consumption per capita was $23.56 \mathrm{~kg}$ in 2006 increasing to $32.59 \mathrm{~kg}$ in 2010 . Nevertheless, this number is still far below the reccommended standard of Food Agricultural Organization (FAO) which is $65 \mathrm{~kg}$ per capita per year.

Duku (Lansium domesticum Corr.) is a fruit tree originated from Indonesia and has been widely distributed across Indonesia with the production center located in Sumatra island (South Sumatra, West Sumatra, and Jambi), Java island (Central Java and Jakarta), and Kalimantan island (West Kalimantan) (Directorate General of Horticulture, 2015). Duku fruit is considered to have a high commercial value and competitive to other fruit commodities. It is favorited due to its sweet taste and odorless smell and it also has fairly nutrient content. In every $100 \mathrm{~g}$, it contains $42 \mathrm{cal}, 0.7 \mathrm{~g}$ protein, $13 \mathrm{~g}$ carbohydrate, $13.0 \mathrm{mg}$ calcium, $20.0 \mathrm{mg}$ phosphorus, $3.2 \mathrm{~g}$ fiber, $0.06 \mathrm{mg}$ vitamin $\mathrm{B} 1,3.8 \mathrm{mg}$ vitamin $\mathrm{C}$ and $0.9 \mathrm{mg}$ Zinc (Mayanti, 2009). Yet, duku production in Indonesia is recently in the decreasing trend. The production in $2012-2014$ in respectively was 258,$453 ; 233,118 ; 208,424$ ton per ha per year (Central Bureau of Statistic, 2015).

South Sumatra Province is one of germplasm center of various fruit commodities, especially duku plant. South Sumatra duku production was 10,457 ton contributing in $5.02 \%$ of national duku production (Central Bureau of Statistic, 2015). Duku originated from South Sumatra is very popular and even has its own trade mark in the national market with the nickname of "Duku Palembang", while in the local South Sumatra market is known as 
"DukuKomering". Therefore, South Sumatra government has determined duku as mascot flora in the province (Deroes and Wijaya, 2010).

Duku plants in South Sumatra are mostly grown along the river basins of Komering, Ogan, Lematang, and MusiRiver distributed in seven regencies which are Ogan Komering Ulu (OKU), OganKomeringllir (OKI), Banyuasin, Musi Banyuasin, Muaraenim, Musi Rawas and Lahat. Duku plant from each regency has different phenology in both vegetative and generative (fruit quality) growth. Duku of OKU has been determined as variety based on the Decree of Agricultural Ministry No. 31/Kpts/tp.240/95 stating that Rasuan cultivar and Palembang cultivar were appointed as two national duku varietiesoriginated from South Sumatra (Seed Inspection and Certification Center of South Sumatra, 1999). However, both cultivars are most known in national market as Duku Palembang. The characteristics of Duku Palembang are the sweet taste and thin fruit peel (Uji, 2007).Duku cultivation is potential to be developed commercially due to the high demand of duku fruit for either freshly consumption or fruit drink ingredients. Furthermore, duku price is relatively higher compared to other similar commodities. This condition should be used as a great opportunity for increasing the income and welfare of duku farmers and duku related stakeholders (Pane, 2011).

The development of duku plantation in other regencies is required to enrich duku germplasms in South Sumatra. BanyuasinRegency in South Sumatra was chosen as research location for this study since there are many duku plantations in this area. Kusandaryani and Luthfy (2006) stated that the efforts to anticipate plant gene erosion by conserving the genetic materials were needed to be performed, either through exploration, characterization, rejuvenation, or documentation.

The inventory activities in several locations in Banyuasin was conducted to collect the data of duku accession in these areas. The activities included exploration and identification (Yuniarti, 2011). Plant morphological identification was carried out by observing the leaves, stems, flowers, fruits, roots and other morphological characteristics. The characteristic that could be used as anatomy marker is leaf stomata (Damayanti, 2007). Physiological characteristics such as nitrogen content, leaf chlorophyll and leaf sucrose were essential to indicate photosynthesis process in plant. Hanumet al. (2013) stated that the characters of morphology, anatomy and physiology were affected by both environment and genetic. Environmental difference will result in varied characters in plant creating many accessions in some locations. Morphological variation in duku plants are shown in the trees, leaves and fruits.

Thus, the study was conducted to observe the correlation among vegetative and generative characters of duku accession in Banyuasin Regency. The data obtained could further utilized as a base information for Banyuasin duku position as duku germplasm resource in South Sumatra.

\section{MATERIALS AND METHODS OF RESEARCH}

Materials used in this study consisted of: duku plant samples, aceton $80 \%$, sticky tape, filter paper, plastic bag, labelling paper, nail polish, transparent plastic, plastic rope, munsell color chart of plant tissue, cooling box, scissors, hygrometer, canon camera PowerShot SX $520 \mathrm{HS}$, compass, laser portable leaf area meter-1-202, microscope celettron-screen, ruler, gauge, manual of leaf architecture, analytical balance, electric oven, spectrophotometerUNICO 1100, aluminum ladder, calipers, and refractometer. The research was conducted for 10 months in 2017 located in three areas of Banyuasin Regency, which are Banyuasin $1\left(\mathrm{BA}_{1}\right)$, Banyuasin $2\left(\mathrm{BA}_{2}\right)$ and Banyuasin $3\left(\mathrm{BA}_{3}\right)$.

Methods used were survey and literature study. Sampling was performed by using purposive sampling method. Five plant samples were observed in each location resulted in total 15 plant samples. Research steps included survey, research sites determination, and purposive sampling. Vegetative characters were observed in stems and leaves, while fruits were observed for the generative characters. The observation in stem morphology consisted of the parameters of plant height, stem girth and branching type. The analysis of leaf 
morphology, leaf anatomy and leaf physiology was carried out in the laboratory of Plant Physiology, Department of Agronomy, Faculty of Agriculture, University of Sriwijaya.

Leaf chlorophyll was analyzed by soaking $2 \mathrm{~cm} \times 2 \mathrm{~cm}$ of fresh leaf samples into $10 \mathrm{ml}$ of ethanol $80 \%$ for about 48 hours in dark room. The absorbance then was determined using spectrophotometer with 650 and $665 \mathrm{~nm}$ of wavelength (Hall and Rao, 1987). Antrone method was used to determine leaf sucrose. $2 \mathrm{~g}$ of fresh leaf was added with $15 \mathrm{ml}$ of ethanol then crushed in the mortar. Another $10 \mathrm{ml}$ of ethanol then was added to the crushed leaf samples. It was then filtered and heated in $70{ }^{\circ} \mathrm{C}$ temperature for 30 minutes. After cooling down, $0.2 \mathrm{ml}$ of sample solution was added with $6 \mathrm{ml}$ antrone $(0.25$ antrone +177.5 $\mathrm{ml} \mathrm{H}_{2} \mathrm{SO}_{4}+72.5 \mathrm{ml}$ of water). The solution was heated until it changed into blue-ish color. After cooling down, the absorbance was determined using spectrophotometer with $600 \mathrm{~nm}$. Leaf nitrogen was determined by using Kjeldahl method. $0.1 \mathrm{~g}$ of dry samples added with strong sulphate acid was heated in the acid room. Destillation process then was performed by using Borax acid and indicator. The solution then was titrated with $0.01 \mathrm{~N}$ of sulphate acid until the color changed into red (Lorenz, 1978).

Data resulted then were descriptively analyzedand calculated for the correlation among characters. Phenotypic variance analysis and deviation standard were used to determine the range (large or narrow) of the observed characters' variability. Deviation standard and phenotypic variance were also calculated. Characters variability was determined based on Daradjat (1987) method. Large variability was occurred when the variance was bigger than twice of deviation standard $\left(\sigma_{f}^{2}>2 . S \mathrm{~d} \sigma_{f}^{2}\right)$, and narrow variability when the variance is less than twice of deviation standard.All collected data were presented in form of tables and figures.

\section{RESULTS AND DISCUSSION}

Vegetative Characters. The characters of morphology, anatomy and physiology were observed as the vegetative characters. Morphological characters then were divided into quantitative and qualitative morphology.
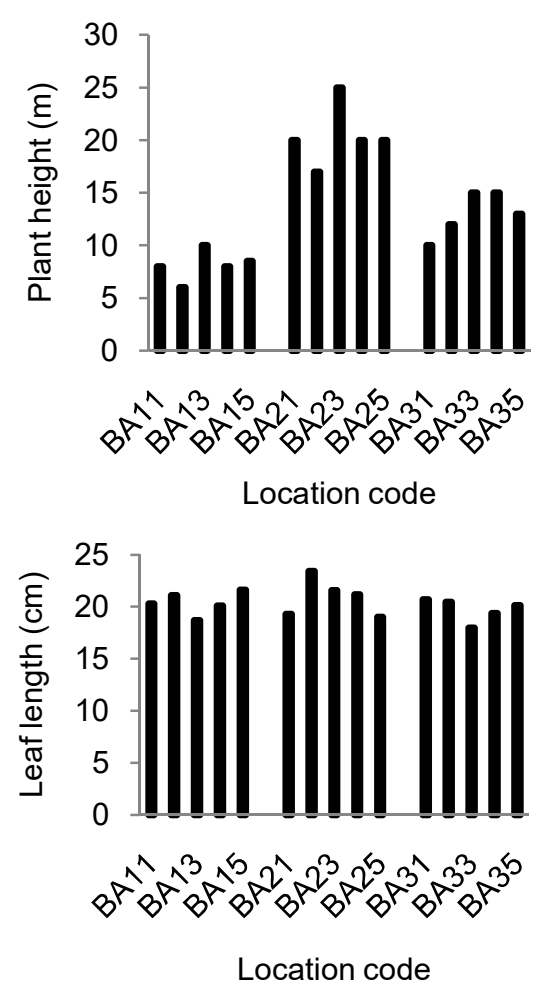
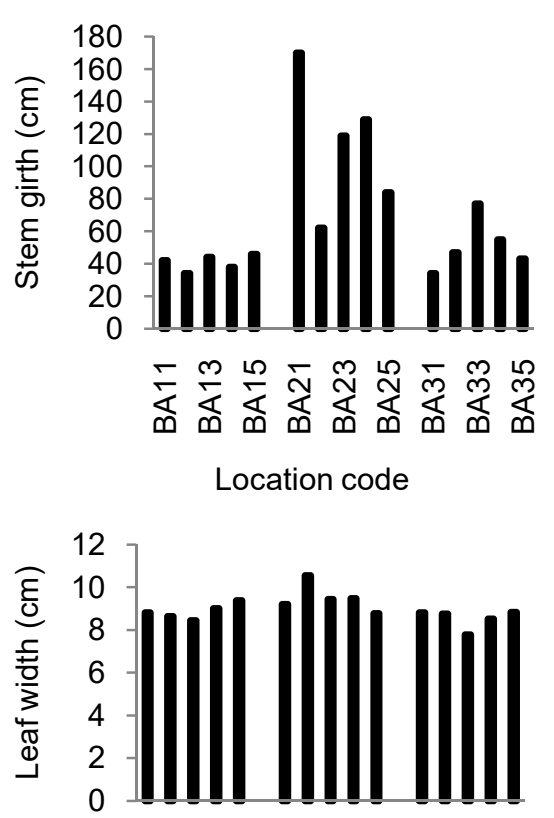

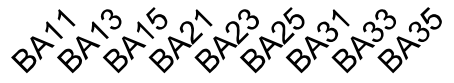

Location code

Figures 1-4 - Vegetative Characters 
Quantitative morphology then was used as phenotypic variability analysis. The observation for quantitative morphology obtained the data of plant height, stem girth and leaf width.

The tallest tree was found in $\mathrm{BA}_{23}$ location with $25.0 \mathrm{~m}$ and the lowest was in $\mathrm{BA}_{12}$ with $6.0 \mathrm{~m}$. The largest stem girth was $\mathrm{BA}_{21}$ with $170 \mathrm{~cm}$ and the smallest was in $\mathrm{BA}_{12}$ and $\mathrm{BA}_{31}$ with $34 \mathrm{~cm}$. The longest and widest leaf was found in the same location in $\mathrm{BA}_{22}$ with $23.43 \mathrm{~cm}$ and $10.55 \mathrm{~cm}$ respectively. However, the shortest and narrowest leaf was from different location. The shortest leaf was in $\mathrm{BA}_{13}$ with $18.71 \mathrm{~cm}$ and the narrowest leaf was in $\mathrm{BA}_{33}$ with $7.78 \mathrm{~cm}$. The difference in leaf morphology was due to the difference in temperature, humidity, and light intensity intercepted by the leaves (Pompelliet al., 2010; Sholikhahet al. 2015)(Figure 1-4).

The qualitative morphology based on Munsell Colour Book and Manual of Leaf Architecture (Ash et al., 199)showed the similarity for all the observed characters in all locations.The branching type was monopodial with an obvious main stem which was bigger and taller compared to the branches. The branches direction was also tend to go upward.Leaf shape was elliptic with 1.5-2 : 1 of comparison between leaf length and leaf width while leaf petiole was on the lamina.Leaf margin was entire with thin segment and no fiber layer. Leaf base shape was complex and leaf tip was acuminate, while leaf venation type was a pinnate with single leaf vein. Leaf greeness level was 3/4 7.5 GY (data not shown).

Both quantitative and qualitative data for leaf anatomy were obtained through microscopic observation. Quantitative data includednumber of abaxial and adaxial stomata, and stomata shape was as qualitative data. The number of abaxial stomata was relatively higher than adaxial stomatafor about 20.75 - 29.50 in which the highest was found in $\mathrm{BA}_{25}$ and the lowest was in $\mathrm{BA}_{11}, \mathrm{BA}_{23}$ and $\mathrm{BA}_{31}$, while adaxial stomata was around $5.75-$ 9.25 where the highest was in $\mathrm{BA}_{14}$ and the lowest was in $\mathrm{BA}_{32}$ (Figure 5). Stomata number was counted in each microscopic viewing with $40 \times 10$ magnification.According to Yuliasmara and Ardiyanti (2013), leaf would tend to have more number of leaf stomata on the under surface of the leaf compared to the leaf surface. The higher number of stomata, the higher stomata density. Yulianti et al. (2010) stated that stomata density could be determined as the character identifying plant disease resistancy.

Result showed that stomata shape was anomocytic shapecharacterizedby the guard cell surrounded by five or more epidermic cells so that the shape would look like a pentagon. Based on stomata position, duku leaf was identified as an amphystomatic type (data not shown). It is a type of leaf that has stomata in both sides of the leaf (Rushayati and Maulana, 2005).

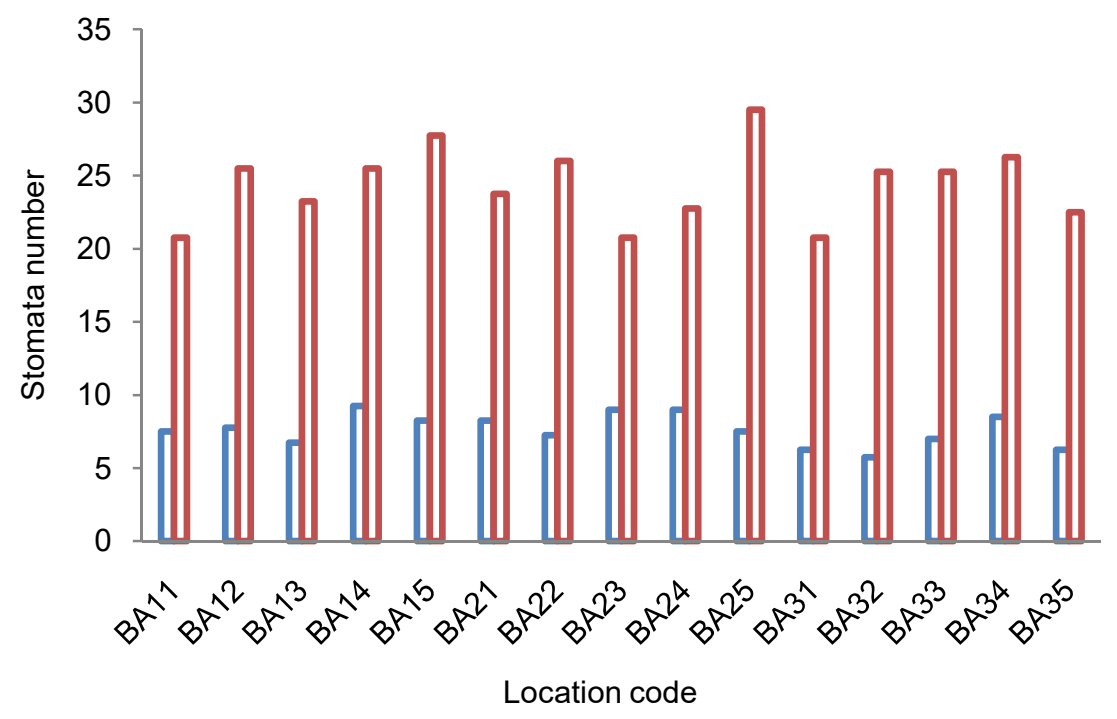

Figure 5 - Adaxial and abaxial stomata of duku accession in Banyuasin Regency 
Leaf chlorophyll was analized in the laboratory resulting in $10.54-30.45 \mathrm{mgg}^{-1}$ of chlorophyll content. The highest was resulted in location $\mathrm{BA}_{13}$ and the lowest was in $\mathrm{BA}_{14}$ (Figure 6). Leaf nitrogen was around $0.28-1.68 \%$ and leaf sucrose was $0.03-0.44 \%$. The highest nitrogen was from $B A_{31}$ and the lowest was from $B A_{21}$, while for sucrose the highest was $B_{21}$ and the lowest was $B_{13}$ (Figure 7). Ai Song and Banyo (2011) stated that leaf chlorophyll was influenced by environmental factors such as light intensity and $\mathrm{H}_{2} \mathrm{O}$. Leaf nitrogen could be used as an indicator for photosynthesis activity since nitrogen is one the constituent elements of chlorophyll required for carbohydrate formation in photosynthesis (Hernita et al., 2012). Anggarwulan et al. (2008) added that leaf nitrogen was also influenced by $\mathrm{H}_{2} \mathrm{O}$. Leaf sucrose resulted a varied data which might be caused due to either environmental (such as ground water content) or genetical factor by SUT gene expression or sucrose transporter (Novita et al., 2007).

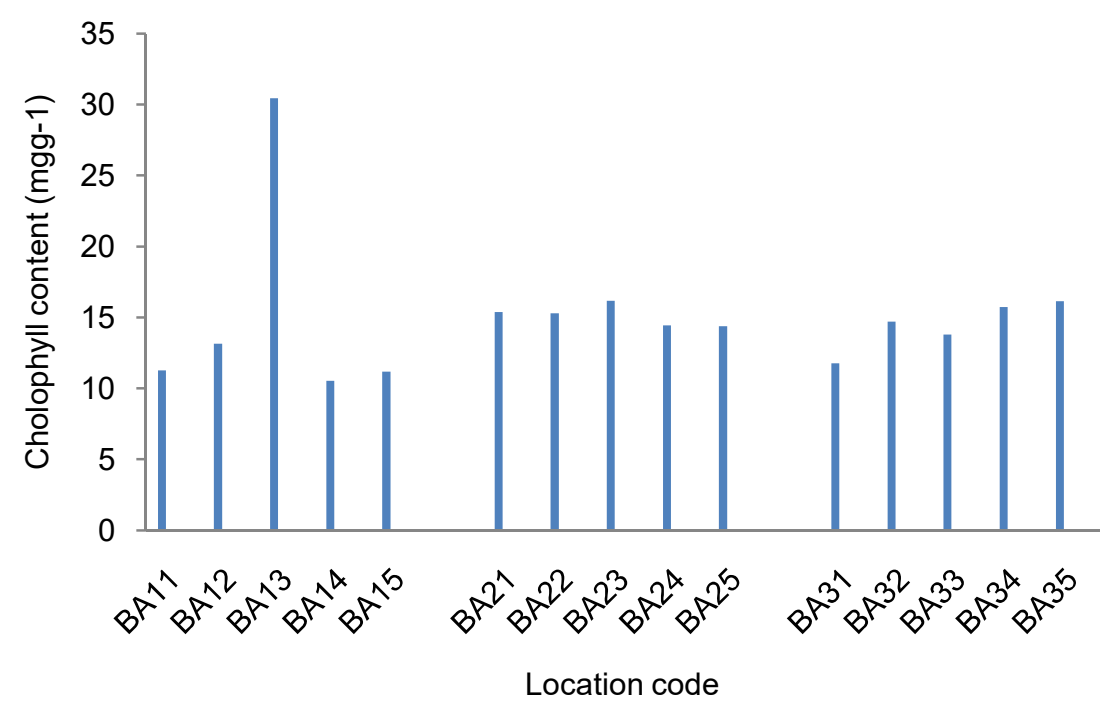

Figure 6 - Leaf chlorophyll of duku accession in Banyuasin Regency

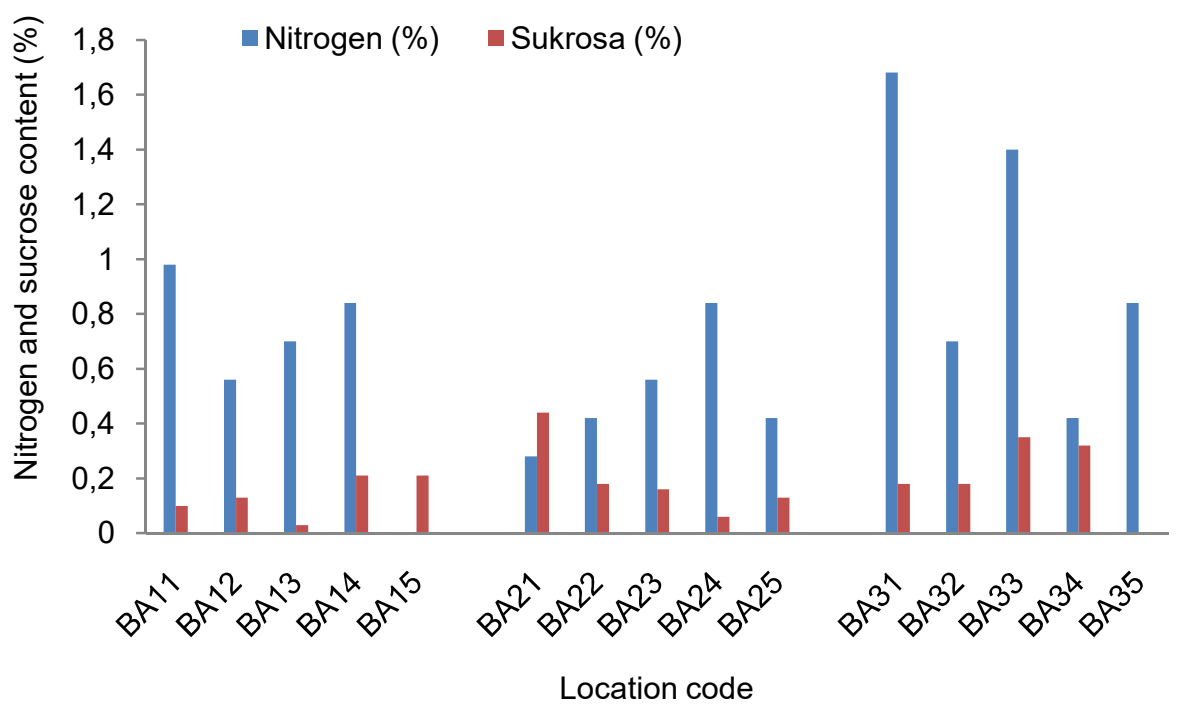

Figure 7 - Leaf and sucrose content of duku succession in Banyuasin Regency

Generative Characters. The obtained data of generative characters consisted of fruit length $(\mathrm{cm})$, fruit diameter $(\mathrm{cm})$, fruit peel thickness $(\mathrm{g})$, fruit weight $(\mathrm{g})$, number of slices per fruit, number of seed per fruit and sweetness level ( ${ }^{\circ}$ brix). Fruit length was around $2.70-$ $3.46 \mathrm{~cm}$ where the longest fruit was resulted from location $\mathrm{BA}_{25}$ and the shortest was in $\mathrm{BA}_{22}$. 
Fruit diameter was around $2.18-2.71 \mathrm{~cm}$ where the largest was in $\mathrm{BA}_{12}$ and the smallest was in $\mathrm{BA}_{33}$. Fruit peel thickness was around $0.15-0.23 \mathrm{~cm}$ where the thickest was in two locations $\mathrm{BA}_{25}$ and $\mathrm{BA}_{34}$, while the thinnest was in $\mathrm{BA}_{22}$ (Figure 8).

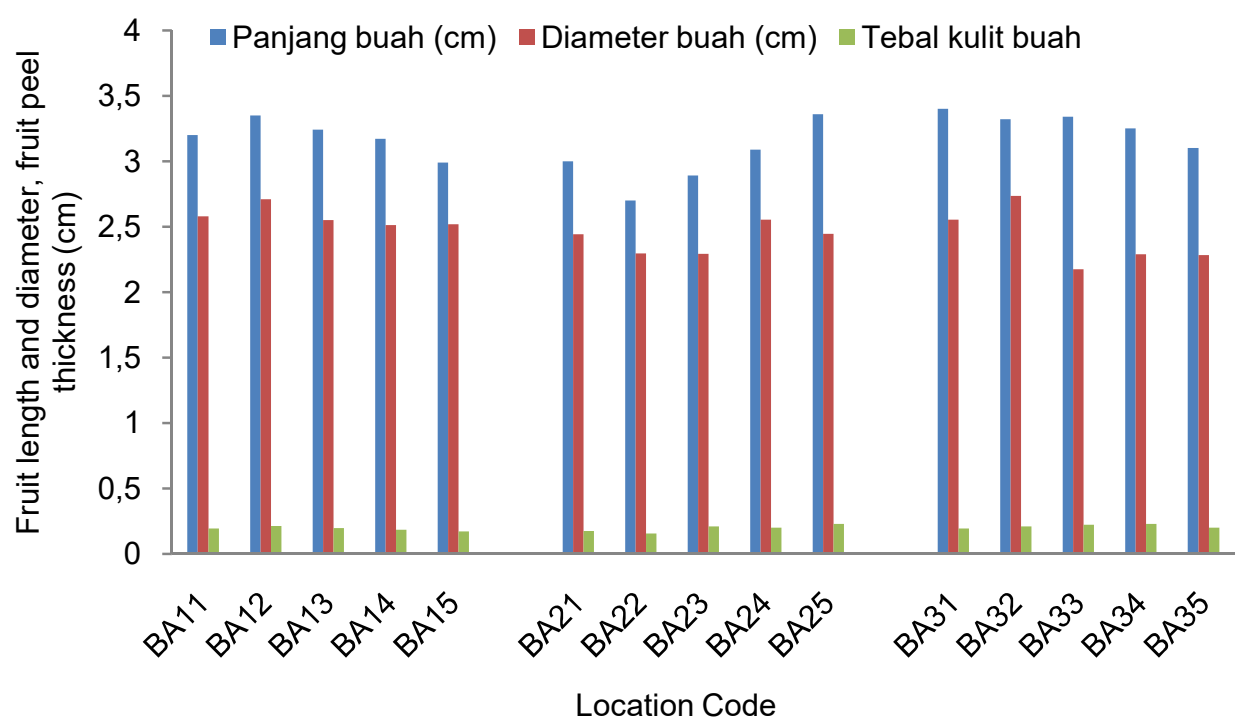

Figure 8 - Fuit length, diameter and fruit peel thickness of duku accession in Banyuasin Regency

Fruit weight was around $9.26-16.10 \mathrm{~g}$ where the heaviest was in $\mathrm{BA}_{12}$ and the lightest was resulted from two locations $\mathrm{BA}_{21}$ and $\mathrm{BA}_{31}$ (Figure 9). Number of slices per fruit was around $4.67-5.00$ where the highest number was resulted from 4 locations: $\mathrm{BA}_{12}, \mathrm{BA}_{13}$, $\mathrm{BA}_{14}$ and $\mathrm{BA}_{22}$. While the lowest number was in $\mathrm{BA}_{34}$ (Figure 10). Seed number per fruit was around $0.00-0.83$ where the highest was in $\mathrm{BA}_{11}$ and the lowest was in $\mathrm{BA}_{21}$ (Figure 11). Sweetness level was around $18.82-22.28{ }^{\circ}$ brix. The highest was in $\mathrm{BA}_{25}$ and the lowest was in $\mathrm{BA}_{34}$ (Figure 12).

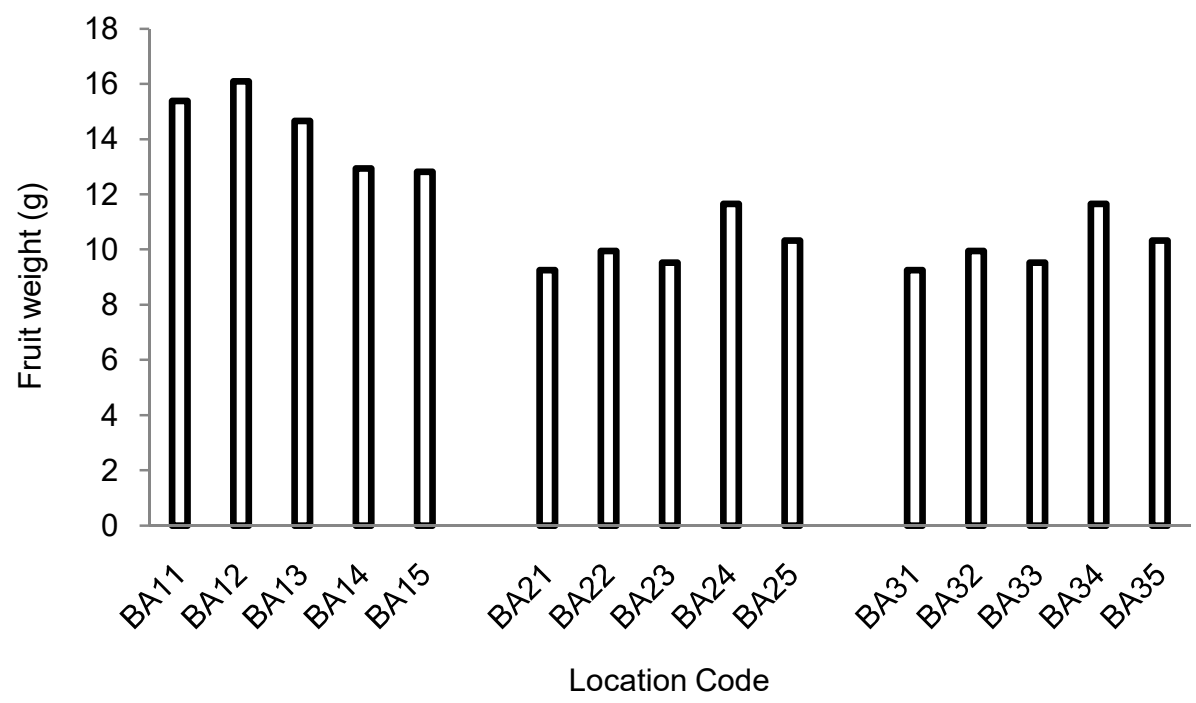

Figure 9 - Fruit weight of duku accession in Banyuasin Regency

Analysis of Variability and Correlation among Characters. Phenotypic variability analysis was performed based on the characters of quantitative morphology, quantitative anatomy and physiology. Results showed that both wide (varied) and narrow (similar) variability were found in the accession of duku in Banyuasin Regency (Table 1). 


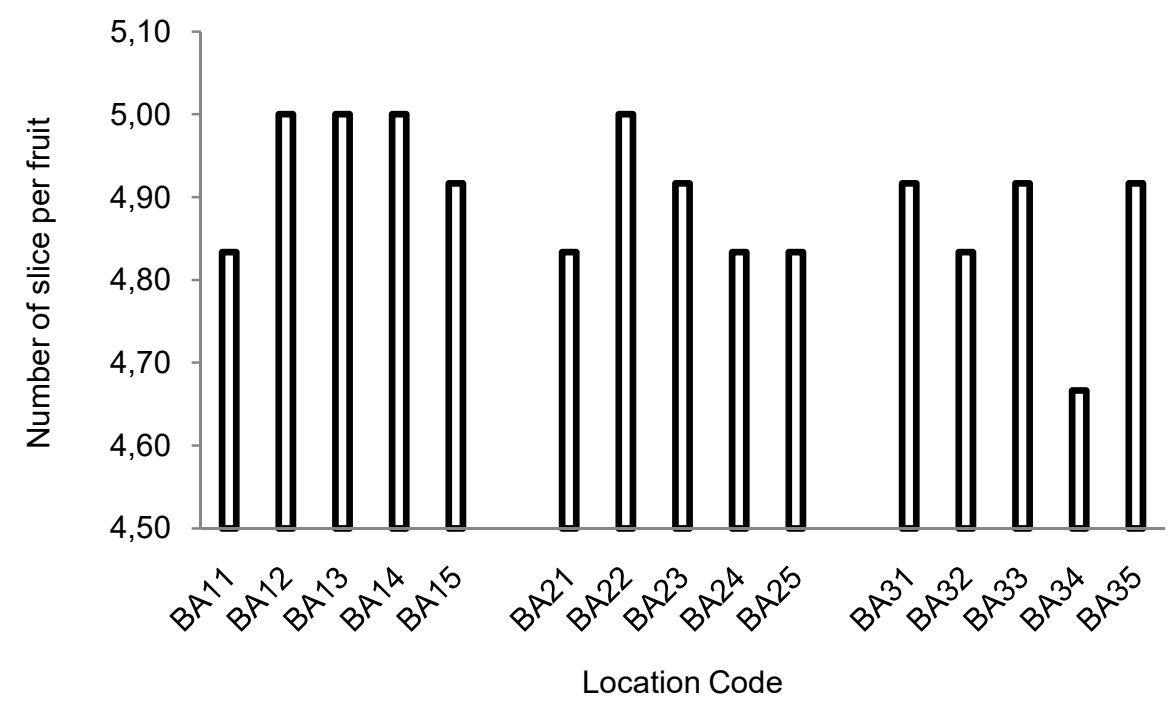

Figure 10 - Number of slice per fruit of duku accession in Banyuasin Regency

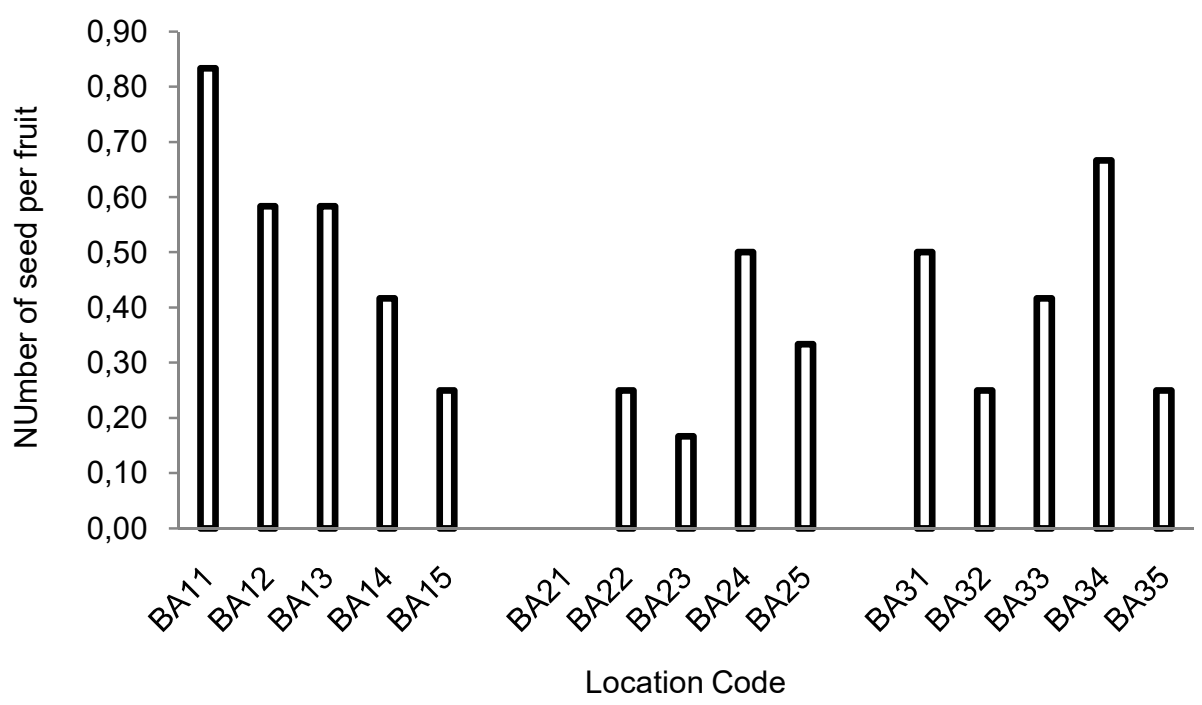

Figure 11 - Number of seed per fruit of duku accession in Banyuasin Regency

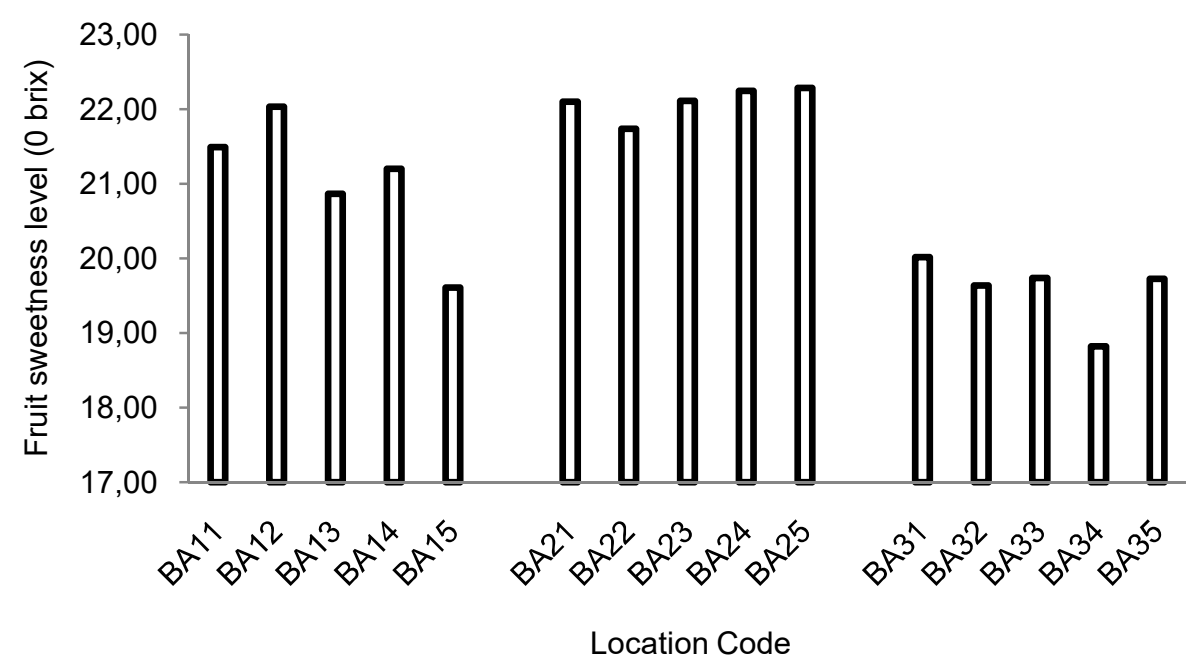

Figure 12 - Fruit sweetness level of duku accession in Banyuasin Regency 
Table 1 - Variability analysis of duku accession in Banyuasin Regency

\begin{tabular}{llll}
\hline Characters & Variance & Deviation standars & Variability \\
\hline Tree height $(\mathrm{m})$ & 38.34 & 1.68 & Wide \\
Stem girth $(\mathrm{cm})$ & 1514.45 & 26.61 & Wide \\
Leaf length $(\mathrm{cm})$ & 0.35 & 1.27 & Narrow \\
Leaf width $(\mathrm{cm})$ & 0.48 & 0.62 & Narrow \\
Number of adaxial stomata & 0.58 & 0.69 & Narrow \\
Number of abaxial stomata & 0.10 & 3.81 & Narrow \\
Leaf chlorophyll $\left(\mathrm{mgg}^{-1}\right)$ & 0.22 & 0.71 & Narrow \\
Leaf nitrogen $(\%)$ & 0.06 & 0.28 & Narrow \\
Leaf sucrose $(\%)$ & 0.004 & 0.45 & Narrow \\
Fruit weight $(\mathrm{g})$ & 3.484 & 1.866 & Narrow \\
Fruit length $(\mathrm{cm})$ & 0.019 & 0.137 & Narrow \\
Number of slice per fruit & 0.003 & 0.051 & Narrow \\
Number of seed per fruit & 0.020 & 0.140 & Narrow \\
Fruit peel thickness $(\mathrm{cm})$ & 0.000 & 0.011 & Narrow \\
Fruit sweetness $\left({ }^{0}\right.$ Brix $)$ & 1.589 & 1.260 & \\
\hline
\end{tabular}

Note: variability determined using the method of Daradjat (1987).

Large variability was resulted when the variance was more than twice of deviation standard, while if the variance was less than twice of deviation standard, narrow variability was resulted. Large variability was resulted from the characters of tree height and stem girth, while other characters resulted a narrow variability. The difference of variability might be caused by envionmental factor (phenotypic variability) and genetic factor (genetic variability). According to Ruchjaningsih et al. (2002), a character with narrow variability indicated a relatively simiar population so that it was rather impossible to carry out a selection for character improvement. Furthermore, Alnopri (2004) added that large variability was considered as one of selection requirements for certain desired character.

Table 2 - Correlation among vegetative and generative characters of duku accession

\begin{tabular}{|c|c|c|c|c|c|c|c|c|c|c|c|}
\hline Characters & $\overline{\mathrm{TH}}$ & SG & $\overline{\mathrm{LL}}$ & LW & FL & FD & FW & SLPF & SDPF & FPT & $\mathrm{SL}$ \\
\hline $\mathrm{TH}$ & 1 & $0.823^{* *}$ & 0.040 & 0.325 & -0.426 & $-0.533^{*}$ & $-0.673^{* *}$ & -0.332 & $-0.524^{*}$ & 0.201 & -0.080 \\
\hline SG & & 1 & -0.070 & 0.262 & -0.387 & -0.274 & $-0.465^{\star}$ & -0.305 & $-0.531^{*}$ & 0.028 & -0.075 \\
\hline LL & & & 1 & $0.861^{\text {** }}$ & $-0.659^{* *}$ & 0.136 & 0.002 & 0.295 & -0.187 & $-0.625^{\star *}$ & 0.088 \\
\hline LW & & & & 1 & $-0.849^{* *}$ & -0.033 & -0.180 & 0.196 & -0.410 & $-0.723^{* *}$ & 0.023 \\
\hline $\mathrm{FL}$ & & & & & 1 & 0.382 & 0.213 & -0.203 & $0.503^{*}$ & $0.672^{* *}$ & -0.087 \\
\hline FD & & & & & & 1 & $0.513^{*}$ & 0.100 & 0.262 & -0.078 & 0.065 \\
\hline FW & & & & & & & 1 & 0.225 & $0.680^{* *}$ & -0.028 & -0.039 \\
\hline SLPF & & & & & & & & 1 & -0.147 & -0.489 & 0.377 \\
\hline SDPF & & & & & & & & & 1 & 0.280 & -0.284 \\
\hline FPT & & & & & & & & & & 1 & -0.198 \\
\hline SL & & & & & & & & & & & 1 \\
\hline
\end{tabular}

Note: $T H=$ tree height; $S G=$ stem girth; $L L=$ leaf length; $L W=$ leaf width; $F L=$ fruit length; $F D=$ fruit diameter; $F W=$ fruit weight; SLPF = number of slice per fruit; SDPF = number of seed per fruit; FPT = fruit peel thickness; $S L=$ sweetness level. ${ }^{*}=$ significant in 0.05 level; ${ }^{* *}=$ significant in 0.01 level.

Based on the correlation analysis of vegetative and generative charaters, it was found that tree height had significant positive correlation with stem girth and significant negative correlation with fruit diameter and number of seed per fruit, and also had significant correlation with fruit weight. Stem girth showed a significant negative correlation with number of seed per fruit. While leaf length had significant positive correlation with leaf width and significant negative correlation with fruit length and fruit peel thickness. Leaf width showed significant negative correlation with fruit length and fruit peel thickness. Fruit length had significant positive correlation with number of seed per fruit and fruit peel thickness. Fruit diameter showed siignificant positive correlation with fruit weight, and fruit weight was positively correlated with number of seed per fruit significantly. 


\section{CONCLUSION}

Based on the obtained results, it was concluded that postive correlation was resulted among vegetative characters and also among generative characters, while vegetative and generative characters were negatively correlated.

\section{REFERENCES}

1. Ai Song A., and Y. Banyo. 2011. Chlorophyll Concentration as the Indicator of Water Deficit in Plant. J. IImiah Sains 11(2):167-173.

2. Alnopri. 2004. The Genetic Variability and Heritability of Seedling Growth Traits of Seven Genotypes Robusta-Arabica Coffee. JurnallImu-ilmuPertanian Indonesia. Volume 6(2): 91-96.

3. Anggarwulan E, Solikhatun, Widya M. 2008. Physiological characters of kimpul (Xanthosomasagittifolium(L.)Schott) in various of light intensity (shading) and water availability. Biodiversitas 9(4):264-268.

4. Ash, A., B. Ellis., L.J. Hickey., K. Johnson., P. Wilf., dan S. Wing. 1999. Manual of leaf architecture. Morphological description and categorization of dicotyledonous and netveined monocotyledonous angiosperms. Smithsonian institution. Washington.

5. Central Bureau of Statistic. 2015. The Statistic of Indonesian Fruit Production..www.bps.go.id (accessed on June 19, 2016).

6. Damayanti, F. 2007. The Analysis of Chromosome Number and Stomata Anatomy in Several Banana (Musa sp.) Germplasms Originated from East Kalimantan. Bioscientiae. 4(2): 53-61.

7. Daradjat, A.A. 1987. Genotype Adaptation Variability of Wheat Plants on Different Planting Environment in Indonesia .University of Padjajaran. Bandung.

8. Deroes, K.Mand A. Wijaya. 2010. Current Condition and Opportunity for Duku(Lansium Domesticum Corr) Development. J. Pembangunan Manusia 4 (11) : 1-7.

9. Directorate General of Horticulture. 2015. The Information of Horticultures and Other Various Plants. Directorate General of Horticulture. Jakarta. (In Indonesian)

10. Hanum, L., R.S. Kasiamdari., Santosaand Rugayah. 2013. The Character of Macromorphology and Micro-morphology of Duku, Kokosan, Langsatin Determining Taxonomy Status in the Category of Intra-species.JurnalBiospecies Vol. 6 (2): 23-29.

11. Hall, D.O., K.K. Rao. 1987. Photosynthesis. 4thed King's college, University of London, London.

12. Hernita, D., R. Poerwanto., A.D. Susila and S. Anwar. 2012. The Determination of Nutrient Status on Duku Seedlings. J. Hort. 22(1): 29-36.

13. Irawan, B. and K. Purbayanti. 2008. The Characterization and Genetic Relation of Local Rice Cultivar in Rancakalong, Sumedang.PTTI National Seminar,October 21-23, 2008.

14. Kusandaryani, Y. and Luthfy, 2006. The Characterization of Kangkung Germplasms. Buletin plasma nutfah. 12 ( ): $30-33$

15. Lorenz, O.A. 1978. Potential nitrate level in edible plant parts. P. 201-219. In D.R Nielsen J.G. MacDonald (Eds) Nitrogen in The Environment. Academic Press, New York.

16. Novita, H., Sumadi., D.P. Restanto., T.A. Siswoyoand B. Sugiharto. 2007. The Isolation and Characterization of Gene Expression for Protein Sucrose Transporter in Sugarcane. JurnalllmuDasar. 8(2): 118-127.

17. Pane, N., R. Gintingand H. Hasyim. 2009. Farming Business Analysis of Duku(LansiumdomesticumCorr.)Plantation. J. Agroekoteknologi3(2): 92-98.

18. Pompelli, M.F., S.C.V. Martins., E.F. Celin., M.C. Ventrella., dan F.M. DaMatta. 2010. What is the influence of ordinary epidermal cells and stomata on the leaf plasticity of coffe plants grown under full-sun and shady conditions?.Braz. J. Biol., 70(4): 1083-1088.

19. Rohlf, F.J. 1998. NTSys-pc. Numerical Taxonomy and Multivariate Analysis System. Version 2.02. Exerter Software. New York. 
20. Rushayati, S.B., and R.Y. Maulana. 2005. Growth Response and Anatomy of Canary (Canarium commune L.) Leaf and Acacia (Acacia mangiumWilld.) to Vehicle Gas Emission. Media Konservasi.X (2): Desember 2005: 71-76.

21. Ruchjaningsih A., Imaraman, Thamrin M., Kanro M.Z. 2002. Phenotypic Performance of Several Genetic Parameter of Eight Ground Nut Cultivars Grown in Paddy Field. Zuriat 11(1): 110.

22. Seed Inspection and Certification Center of South Sumatra. 1999. The Determination of Fruit Parent Trees. Seed Inspection and Certification Center of South Sumatra, Palembang.

23. Sholikhah, U., D.A. Munandar and A. Pradana. 2015. Physiological Characters of Robusta Coffee Clone BP 358 at Different Shading Types. Agrovigor . 8 (1) : 58-67.

24. Yuniarti. 2011. The Inventory and Morphological Characterization of Durian (DuriozibethinusMurr.) in Tanah DatarRegency. J. Plasma nutfah. 1 1) : 1-7.

25. Yulianti, H., D. Siswanto., and J. Purnomo. 2010. The Study of Stomata Density in the Sensitive and Tolerant Cultivar to Leaf Rust PucciniaarachidisSpeg.) in Ground Nut (Arachishipogaea L.). Basic Science national seminar proceeding. Malang. 20 februari 2010. 1-5.

26. Yuliasmara, F and F. Ardiyanti. 2013. Morphology, physiology and anatomy of pakupicisan (Drymoglossumphyloselloides) and its influence on the cocoa tree. Pelita Plantation. 29 (2): 128-141.

(c) 2017 by the authors. Licensee RJOAS, Orel, Russia. This article is an open access article distributed under the terms and conditions of the Creative Commons Attribution (CC BY) license: http://creativecommons.org/licenses/by/4.0/ 